\title{
Exploring Femininity in Ama Ata Aidoo's Anowa: An Interpersonal Analysis
}

\author{
Issa Djimet, \\ $\mathrm{PhD}$ in Applied Linguistics, \\ Faculty of Arts and Humanities (FLASH), University of Doba, Chad \\ Leonard A. Koussouhon, \\ Full Professor of Applied Linguistics, African and English Literature, \\ English Department, University of Abomey-Calavi, Benin
}

URL:http://dx.doi.org/10.19044/esj.2020.v16n5p183

\begin{abstract}
This paper aims at analyzing Anowa, a play written by Ama Ata Aidoo, in order to decode the author's conception of femininity which, in the majority of classical literary works produced by men, is traditionally limited to some debasing roles defined by the patriarchal system. The analysis is carried out on the basis of Systemic Functional Linguistics, a theory mainly developed by Halliday and Mathiessen (2004) and Eggins (1994). According to this theory, language is a very complex semiotic system, structured to express three Kinds of meanings simultaneously: the interpersonal, the experiential, and the textual meanings. The article focuses on the interpersonal metafunction in order to find out what characterizes the relationship between men and women, and how this is redefined and to which extent. The methodology used for the analysis is the mixed-method. It comes out from the analysis that the relationship between male and female characters is based on equal power, mutual respect, and familiarity, which is in total contradiction to the description of this relationship in many male authored literary works. Thus, in Anowa, a woman is not an object; but she is equipped verbally and intellectually to talk of herself. Narrations are not insignificant, but they contribute in constructing new identities.
\end{abstract}

Keywords: Femininity, interpersonal metafunction, equal power, respect, familiarity

\section{Introduction}

Generally African women are represented as mere mothers, sisters, aunts, or even prostitutes, etc., who play secondary roles in pre-independence and even post-independence literature. Writers like Senghor, Laye, and 
Achebe, among others, produced literary works that perpetuate debasing descriptions of the African woman. In his poem The Black Woman (Sylvester, 2009), Senghor praises the African woman as beauty but not as an important actress in her society. Similarly, Laye's poem, to my mother, which introduces his novel The African Child, depicts woman as an educator, the one whose principal responsibility is to prepare her child or children to face the challenges of life. Thus, the description of women, mainly in male authored literature, does not attribute preeminent roles to women, contributing to reinforce, in a way, the patriarchal system. This system places women at a disadvantaged position while according important privileges to men.

More and more female writers and feminists are taking up their pens to produce works that redefine femininity in order to build a more just society (Sheik and Ahmat, 2015). Novels, dramas, and poems written for this purpose represent a new society, a society in which women's standing is increased. This article aims at analyzing Aidoo's Anowa from a systemic functional perspective in order to find out how the author redefines her female characters through mood patterns. The paper focuses on the interpersonal level of language, particularly on linguistics elements such as moods types, adjuncts and modality so as to decode the various dimensions of tenor expressed through the exchange.

\section{Methodology}

This study deals with an interpersonal analysis of two extracts from Aidoo's Anowa. The methodology used for the analysis is the mixed-method approach which consists in combining qualitative and quantitative data in a research study (Creswell, 2014). Indeed, the extracts are selected on the qualitative basis, taking notably into account the relevance of these extracts in terms of the involvement of female characters in them. The extracts are long enough-four pages in font 10-to account for this implication. They are then split into numbered clauses labeled interpersonally. The statistics related to the occurrence of the different mood patterns are provided quantitatively and analyzed on both the quantitative and qualitative basis.

\section{Theoretical Background}

\subsection{The Mood Theory}

Language is generally defined as a means of communication, but this definition does not explicitly say what is communicated through language and how. The systemic functional approach gives an exact idea about the functioning of language. Systemicists define language as a complex semiotic system that is used for communicating three meanings, which are actually its basic functions (Halliday and Matthiessen, 2004, and Eggins, 1994): the interpersonal, the experiential and the textual. While the experiential meaning 
deals with text as a representation of human experience, the interpersonal one is basically about how language is used to convey meanings related to power, solidarity and familiarity conveyed through exchange among interactants. Regarding the textual meaning, it is basically about the thematic structure of the discourse, that is, how the text hangs together in terms of cohesion and continuity.

The interpersonal meaning is mainly actualized by means of dialogue. We use langue to establish social identities such as friends, strangers, male, female, etc., notably through the speech roles we take on in an interaction and their corresponding mood types (Eggins, 1994). Table 1 summarizes the speech functions and their corresponding mood types:

Table 1: Speech functions and their corresponding mood types

\begin{tabular}{l|l}
\hline Speech functions & Mood types \\
\hline Command & Imperative mood \\
\hline Offer & Modulated interrogative mood \\
\hline Statement & Declarative mood \\
\hline Question & Interrogative mood \\
\hline
\end{tabular}

Moreovoer, adjuncts canactualize interpersonal meanings. They are defined "as clause elements which contribute some additional (but not essential) information to the clause" (Eggins, 1994: 165). There are three types of adjuncts: experiential, textual and interpersonal. Experiential adjuncts add interpersonal meanings to the clause by clarifying circumstances relating to time, place, cause, matter, etc. Textual adjuncts connote meanings that have to do with cohesion and continuity in text. As regards interpersonal or modal adjuncts, they are very important elements in the analysis of text as a exchange, for they add meanings relating to probability and usually, familiarity, intimacy, solidarity, etc. There are four types of modal adjuncts:

$\checkmark$ Mood adjuncs

$\checkmark$ Polarity adjuncts

$\checkmark$ Comment adjuncts

$\checkmark$ Vocative adjuncts

Modality is also an important element in the analysis of interpersonal meanings. It has two components: modalisation and modulation. Modalisation refers to the linguistic possibilities that enable the expression of the various degrees of certainty and usuality by means of elements such as perhaps, maybe, often, sometimes, etc used in proposition. Concerning modulation, it has to do with the expression of various attitudes relating to inclination and obligation in proposals. Both modalisation and moduation are used for the expression of different judgements that may be implicit in interactions. 


\section{Mood Analysis of the Two Extracts from Anowa}

\subsection{Mood Analysis of Extract 1}

\subsubsection{Analysis of Mood Types in Extract 1}

The different Mood types analyzed in extract 1 are summarized in table 1 below:

Table 1: Mood Types Statistics in Extract 1

\begin{tabular}{c|c|c|c|c|c}
\hline Mood types & Full & Minor & Elliptical & Total & Percentage \\
\hline DM & 182 & 12 & 05 & 199 & $68.15 \%$ \\
\hline IntM & 55 & 00 & 02 & 57 & $19.52 \%$ \\
\hline ImpM & 20 & 00 & 00 & 20 & $6.84 \%$ \\
\hline EX & 03 & 13 & 00 & 16 & $5.47 \%$ \\
\hline Total & 163 & 24 & 06 & 292 & $100 \%$ \\
\hline
\end{tabular}

The above table shows that the declarative mood type is the most predominant [199/292] (68.15\%), followed by interrogative moods [57/292] (19.52\%), and imperative moods [20/292] (6.84\%). Exclamative moods occur rarely [16/292] $(5.47 \%)$. There is also a significant percentage of minor clauses [24/292] (8.21\%) in the extract, denoting the spoken nature of the text and enabling the realization of interpersonal meanings such as familiarity among the interacrants. The frequent use of the declarative mood and interrogative ones implies that the text is basically concerned with information giving and demanding; the characters make statements and argue about them. Some proposals are also dealt with through the use of imperative moods. Table 2 below recapitulates the distribution of mood types among the participants in extract 1 .

Table 2: Distribution of mood types among the participants in extract 1.

\begin{tabular}{|c|c|c|c|c|c|c|c|c|c|c|c|c|c|}
\hline Participans & $\stackrel{\bar{E}}{\underline{E}}$ & 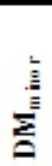 & $\stackrel{\overline{\bar{t}}}{\bar{z}}$ & $\bar{\Xi}$ & 竞 & $\frac{\tilde{z}}{7}$ & $\underline{\underline{E}}$ & & 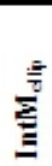 & $\begin{array}{l}\overline{\bar{E}} \\
\text { 音 }\end{array}$ & 咅 & $\frac{\overline{\bar{n}}}{\bar{E}}$ & Total \\
\hline \multirow[t]{2}{*}{ Badua } & \multirow[t]{2}{*}{44} & \multirow[t]{2}{*}{03} & \multirow[t]{2}{*}{00} & \multirow[t]{2}{*}{02} & \multirow[t]{2}{*}{07} & \multirow[t]{2}{*}{00} & \multirow[t]{2}{*}{15} & \multirow[t]{2}{*}{00} & \multirow[t]{2}{*}{01} & \multirow[t]{2}{*}{10} & \multirow[t]{2}{*}{00} & \multirow[t]{2}{*}{00} & 82 \\
\hline & & & & & & & & & & & & & $43.85 \%$ \\
\hline \multirow[t]{2}{*}{ Osam } & \multirow[t]{2}{*}{42} & \multirow[t]{2}{*}{02} & \multirow[t]{2}{*}{03} & \multirow[t]{2}{*}{00} & \multirow[t]{2}{*}{01} & \multirow[t]{2}{*}{00} & \multirow[t]{2}{*}{16} & \multirow[t]{2}{*}{00} & \multirow[t]{2}{*}{01} & \multirow[t]{2}{*}{07} & \multirow[t]{2}{*}{00} & \multirow[t]{2}{*}{00} & 72 \\
\hline & & & & & & & & & & & & & $38.50 \%$ \\
\hline \multirow[t]{2}{*}{ Anow a } & \multirow[t]{2}{*}{17} & \multirow[t]{2}{*}{07} & \multirow[t]{2}{*}{01} & \multirow[t]{2}{*}{00} & \multirow[t]{2}{*}{05} & \multirow[t]{2}{*}{00} & \multirow[t]{2}{*}{03} & \multirow[t]{2}{*}{00} & \multirow[t]{2}{*}{00} & \multirow[t]{2}{*}{00} & 00 & 00 & 33 \\
\hline & & & & & & & & & & & & & $17.64 \%$ \\
\hline Total & 103 & 12 & 04 & 02 & 13 & 00 & 34 & 00 & 02 & 17 & 00 & 00 & 187 \\
\hline
\end{tabular}


As it can be noticed in the table above, the exchange is dominated by Badua, Osam's wife; she utters $43.85 \%$ of the moods whereas her husband (Osam) actualizes $38.50 \%$ of the utterance. Indeed, she utters 43 DMs out of $119(36.13 \%), 16 \mathrm{IntM}$ out of $36(44.44 \%), 10 \mathrm{ImpMs}$ out of 17 (58.82\%), and 09 Exs out of $15(60 \%)$. Thus, she verbalizes more ImpMs than her husband does. As regards Osam, he uses 45 DMs out 119 (37.81\%), 17 IntMs out of 36 (47.22\%), and $01 \mathrm{EX}$ out of $15(6.66 \%)$. Concerning Anowa, she is involved in 24 DMs out of $119(20.16 \%)$ and 05 EXs out of 15 (33.33\%). Despite the sligthness of this domination of the talk by Badua, it shows some kind of selfassertion as it will be explained in the section on discussion.

\subsubsection{Analysis of Modality}

The statistics of modulators and modalizers is summarized in table 3. The table also presents the distributions of these items among the interactants.

Table 3: distributions of modalizers and modulators among participants in Extract 1

\begin{tabular}{c|c|c|c|c|c|c}
\hline Participants & Modalizers & Percentage & Modulators & Percentage & \multicolumn{2}{|c}{ Total } \\
\hline Badua & 20 & $33.33 \%$ & 18 & $51.42 \%$ & 38 & $40 \%$ \\
\hline Osam & 38 & $63.33 \%$ & 09 & $25.71 \%$ & 47 & $49.47 \%$ \\
\hline Anowa & 02 & $3.33 \%$ & 08 & $22.85 \%$ & 10 & $10.52 \%$ \\
\hline Total & 60 & $100 \%$ & 35 & $100 \%$ & 95 & $100 \%$ \\
\hline
\end{tabular}

The table above shows that there is a predominant use of modalizers (60) in the extract in comparaison with modulators (35). This implies that meanings about possibility, frequency or usuality are expressed by the interactants, and attention is given to inclination, permission, and obligation, as well. As it can be verified, Osam authors the majority of modalizers [38/60] (63.33\%) whereas his wife Badua predominates in the use of modulators [18/35] (51.42\%). Actually, it is through such items that she verbalizes her concerns about her daughter's "antisocial" behavior while trying to convince her husband to support her. She and her husband seem to have divergent opinions about the implications of their daughter's attitude. Osam focuses on what would have happened or what will happen, trying somehow to shift the blame on his wife. As far as Anowa is concerned, she is the participant for only $02 / 60$ modalizers (3.33\%) and 08/35 modulators through which she shows her determination to go against culturally accepted norms at the risk of being rejected by her family or the whole of the society.

Table 4 below presents the statistics of the distributions of the modalized and modulated clauses in the extract. 
Table 4: distributions of modal clauses among the Participants in Extract 1

\begin{tabular}{c|c|c|c|c|c|c|c|c|c}
\hline Participants & $\mathrm{M}^{-} \mathrm{DM}$ & $\mathrm{M}^{+} \mathrm{DM}$ & $\mathrm{M}^{+} \mathrm{DM}$ ellip & $\mathrm{M}^{-}$IntM & $\mathrm{M}^{+}$IntM & $\mathrm{M}^{+} \mathrm{EX}$ & $\mathrm{M}^{+} \mathrm{ImP}$ & \multicolumn{2}{|c}{ Total } \\
\hline Badua & 18 & 14 & 01 & 05 & 08 & 01 & 01 & 48 & $45.71 \%$ \\
\hline Osam & 32 & 05 & 00 & 06 & 02 & 00 & 02 & 47 & $44.76 \%$ \\
\hline Anowa & 02 & 08 & 00 & 00 & 00 & 00 & 00 & 10 & $9.52 \%$ \\
\hline Total & 52 & 27 & 01 & 11 & 10 & 01 & 03 & 105 & $100 \%$ \\
\hline
\end{tabular}

It comes out from table 4 that Badua is very active in terms of the use of modality in general [48/105] (45.71\%), modulated and modalized clauses having almost the same number. Osam is involved in almost the same number of modalized and modulated clauses, with a slight predominance of modalized clauses: 38 out of 47 are modalized clauses, representing $80.85 \%$. This confirms what has been noted earlier, that is, he does not play a determing role in his daughter's marriage question, leaving, somehow, his wife to fix it.

\subsubsection{Analysis of Adjunct Types}

Table 5 displays the distribution adjuncts among the participants:

Table 5: distribution of adjunct types among the participants in extract 1

\begin{tabular}{|c|c|c|c|c|c|c|c|c|c|c|c|c|}
\hline 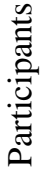 & $\frac{1}{3}$ & ن. & $\underset{>}{>}$ & ن. & 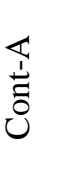 & :ே & $\Xi$ & ن. & $\mathbb{a}$ & ن. & 퐁 & \\
\hline 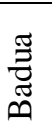 & 24 & $18.18 \%$ & 02 & $7.40 \%$ & 01 & $16.66 \%$ & 04 & $8.16 \%$ & 03 & $20 \%$ & 34 & $\begin{array}{c}14.84 \\
\%\end{array}$ \\
\hline 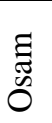 & 30 & $22.72 \%$ & 03 & $11.11 \%$ & 02 & $33.33 \%$ & 07 & $\begin{array}{c}14.28 \\
\%\end{array}$ & 00 & 00 & 42 & $\begin{array}{c}18.34 \\
\%\end{array}$ \\
\hline$\frac{\pi}{3}$ & 31 & $23.48 \%$ & 02 & $7.40 \%$ & 01 & $16.66 \%$ & 17 & $\begin{array}{c}34.69 \\
\%\end{array}$ & 09 & $60 \%$ & 60 & $\begin{array}{c}26.20 \\
\%\end{array}$ \\
\hline 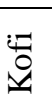 & 47 & $35.60 \%$ & 16 & $59.25 \%$ & 02 & $33.33 \%$ & 21 & $\begin{array}{c}42.85 \\
\%\end{array}$ & 02 & $\begin{array}{c}13.33 \\
\%\end{array}$ & 88 & $\begin{array}{c}38.42 \\
\%\end{array}$ \\
\hline ڤે & 00 & 00 & 04 & $14.81 \%$ & 00 & 00 & 00 & 00 & 01 & $6.66 \%$ & 05 & $2.18 \%$ \\
\hline 䒿 & 132 & $100 \%$ & 27 & $100 \%$ & 06 & $100 \%$ & 49 & $100 \%$ & 15 & $100 \%$ & 229 & $100 \%$ \\
\hline
\end{tabular}

The analysis does not take into account mood adjuncts, for they have been discussed in the section about modality. Table 5 abovepresents the 
distributions of adjuncts types among the interactants. The statistics related to the distribution of adjuncts types among the inetractants exude that Badua authors the majority of adjuncts: 73 out of 164, representing 44.51\%. She utters 53 conjunctive adjuncts out of 103 , corresponding to $51.45 \%$; 13 vocative adjuncts out 44 , that is, $29.54 \%$; 04 circumstantial adjuncts out of 10 , corresponding to $40 \%$. This emphasizes the predominant roles she intends to play in her daughters' life. The majority of vocative [23/44] (52.27\%) adjuncts are uttered by Anowa, showing some kind of respect which is different from submission or obedience. On the whole, conjunctive adjuncts are used for providing "linking relations between one clause and another" (Eggins 1994: 169). As a matter of fact, they ensure coherence and cohesion in the extract. This includes elaboration, enhancement, and extension.

\subsection{Mood Analysis of Extract 2}

\subsubsection{Analysis of Mood Types}

Table 6 below presents the details of mood types in extact 2 :

Table 6: mood types statistics in Extract 2

\begin{tabular}{c|c|c|c|c|c}
\hline Mood types & Full & Minor & Elliptical & Total & Percentage \\
\hline DM & 209 & 12 & 29 & 250 & $63.61 \%$ \\
\hline IntM & 89 & 00 & 17 & 106 & $26.97 \%$ \\
\hline ImpM & 21 & 00 & 00 & 21 & $5.34 \%$ \\
\hline EX & 06 & 08 & 02 & 16 & $4.07 \%$ \\
\hline Total & 163 & 24 & 06 & 393 & $100 \%$ \\
\hline
\end{tabular}

As it can be noted in table 6, declarative moods rank first with a figure of 209 , corresponding to $63.61 \%$; and interrogative moods rank second with a number of 106 , representing $26.97 \%$. As regards the exclamative and the imperative moods, they are few in number, that is, they occur 21 times (5.34\%); whereas exclamatives occur 16 times with a percentage of $4.07 \%$. Thus, the extract is more concerned with proposition rather than with proposal. However, the occurrence of imperative moods suggests that some goods or services are demanded as well. The table also displays a few exclamative moods, meaning that emotions, surprises, and even anger are expressed through the exchanges among the characters. The distributions of the different mood types among the interactants will be the focus of our attention in the following section.

The distribution of mood types among the participants is summarized in table 7: 
Table 7: distribution of mood types among the participants in extract 2

\begin{tabular}{|c|c|c|c|c|c|c|c|c|c|c|c|c|c|}
\hline$\frac{\mathrm{c}}{\frac{\mathrm{c}}{\mathrm{c}}}$ & हूँ & $\frac{1}{2}$ & है & $\bar{z}$ & $\frac{1}{6}$ & बै. & 㐮 & $\sum_{\underline{E}}$ & 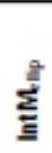 & 를 & 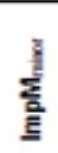 & 总 & Total \\
\hline \multirow{2}{*}{$\frac{\pi}{3}$} & \multirow[t]{2}{*}{22} & \multirow[t]{2}{*}{02} & \multirow[t]{2}{*}{03} & \multirow[t]{2}{*}{00} & \multirow[t]{2}{*}{04} & \multirow[t]{2}{*}{00} & \multirow[t]{2}{*}{12} & \multirow[t]{2}{*}{00} & \multirow[t]{2}{*}{02} & \multirow[t]{2}{*}{00} & \multirow[t]{2}{*}{00} & \multirow[t]{2}{*}{00} & 45 \\
\hline & & & & & & & & & & & & & $16.91 \%$ \\
\hline \multirow{2}{*}{ 퉁 } & \multirow[t]{2}{*}{32} & \multirow[t]{2}{*}{03} & \multirow[t]{2}{*}{02} & \multirow[t]{2}{*}{02} & \multirow[t]{2}{*}{00} & \multirow[t]{2}{*}{00} & \multirow[t]{2}{*}{17} & \multirow[t]{2}{*}{00} & \multirow[t]{2}{*}{04} & \multirow[t]{2}{*}{05} & \multirow[t]{2}{*}{00} & \multirow[t]{2}{*}{00} & 65 \\
\hline & & & & & & & & & & & & & 24.4396 \\
\hline \multirow{2}{*}{ 屁 } & \multirow[t]{2}{*}{34} & \multirow[t]{2}{*}{03} & \multirow[t]{2}{*}{14} & \multirow[t]{2}{*}{00} & \multirow[t]{2}{*}{00} & \multirow[t]{2}{*}{02} & \multirow[t]{2}{*}{11} & \multirow[t]{2}{*}{00} & \multirow[t]{2}{*}{05} & 02 & 00 & 00 & 71 \\
\hline & & & & & & & & & & & & & $26.69 \%$ \\
\hline & 34 & 03 & 03 & 04 & 03 & 00 & 20 & 00 & 06 & 09 & 00 & 00 & 82 \\
\hline$\frac{8}{4}$ & & & & & & & & & & & & & $30.82 \%$ \\
\hline$\vec{z}$ & 00 & 00 & 01 & 00 & 01 & 00 & 01 & 00 & 00 & 00 & 00 & 00 & 03 \\
\hline 8 & & & & & & & & & & & & & $1.12 \%$ \\
\hline $\bar{\pi}$ & 122 & 11 & 23 & 06 & 08 & 02 & 61 & 00 & 17 & 16 & 00 & 00 & 266 \\
\hline ஃँ & & & & & & & & & & & & & $100 \%$ \\
\hline
\end{tabular}

The exchange can be divided into two (02) sections. Section 1: the exchange between Anowa's father and mother (Badua and Osam) and section 2: the exchange between Anowa herself and her husband Kofi Ako. In the section between Osam and Badua, the turn-taking is dominated by Osam who authors 65 clauses out $266(24.43 \%)$ whereas Badua is the participant for 45 clauses out of $266(16.91 \%)$. Thus, here Osam really intends to make himself understood and to express his vision about his daughter's subversive attitude. This domination is also shown through the use of the imperative moods in which he is involved. He utters five (05) out of sixteen (16) ImpMs used in the extract, representing $31.25 \%$ compared to two (02) used by his wife, that is, $12.5 \% .21$ questions are asked by him in comparison with 14 uttered by his wife. Similarly, Kofi Ako plays a central role in the exchange between him and his wife; he is involved in 81 clauses out of 266, representing $30.82 \%$ whereas Anowa is the participant for 71 clauses out of 266, that is, $26.69 \%$. Also, the majority of questions in the conversation between him and his wife are uttered by him, for he authors 26 questions; whereas Anowa is involved in 16 questions. Though the exchange is carried out in an informal tenor context and opinions are freely expressed by female characters, the statistics highlight the efforts made by male characters to have preeminence over their wives.

\subsubsection{Analysis of Modality in Extract 2}

The statistics of modalizers and modulators are summarized in table 8 below: 
Table 8: distributions of modalizers and modulators among the participants in extract 2

\begin{tabular}{c|c|c|c|c|c|c}
\hline Participants & Modalizers & Percentage & Modulators & Percentage & \multicolumn{2}{|c}{ Total } \\
\hline Badua & 16 & $15.38 \%$ & 06 & $20.68 \%$ & 22 & $16.54 \%$ \\
\hline Osam & 19 & $18.26 \%$ & 04 & $13.79 \%$ & 23 & $17.29 \%$ \\
\hline Anowa & 24 & $23.07 \%$ & 04 & $13.79 \%$ & 28 & $21.05 \%$ \\
\hline Kofi & 44 & $42.30 \%$ & 15 & $51.72 \%$ & 59 & $44.36 \%$ \\
\hline Boy & 01 & $0.96 \%$ & 00 & 00 & 01 & $0.75 \%$ \\
\hline Total & 104 & $100 \%$ & 29 & $100 \%$ & 133 & $100 \%$ \\
\hline
\end{tabular}

As it appears from the statistics, there is a predominance of modalisation over modulation in the extract, for the table displays 104 modalizers but only 29 mdulators, meaning that the interactants express their judgements concerning probability, possibility and usuality. The use of modulators implies that judgements with regard to necessity and obligation are also expressed. There is a slight domination of male characters in terms of the use of modal elements: Osam utters 19 modalizers out of 104 (18.26\%) compared to 16 (15.38) used by Badua; Kofi authors 44 modalizers out 104 (42.30\%) compared to 24 (23.07) uttered by Anowa . As far as modulators are concerned, they are essentially verbalized by Kofi-15 out of 29 , that is $51.72 \%$ - which shows his determination to change Anowa's mentality or vision about life or especially women's role. On the whole, modality has served to highlight the interactants beliefs about some facts related to marriage on the one hand, and on the other hand they have served to denounce the evils of slavery through Anowa's utterances. She voices 24/104 modalizers $(23.07 \%)$ and 04/29 modulators $(13.79 \%)$ through which she rejects her husband's idea of living on slaves' labour.

The distribution of modal clauses is recapitulated in table 9: 
Table 9: distribution of modal clauses among the participants in extract 2

\begin{tabular}{|c|c|c|c|c|c|c|c|c|c|c|}
\hline 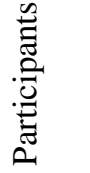 & $\underset{\sum}{\stackrel{\sum}{\sum}}$ & 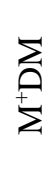 & 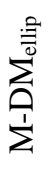 & $\sum_{i}^{0}$ & 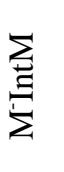 & 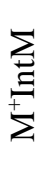 & $\begin{array}{l}\underset{x}{x} \\
\text { 至 } \\
\sum_{\Sigma}^{+}\end{array}$ & $\frac{\vec{g}}{\stackrel{\xi}{z}}$ & 胥 & \\
\hline $\begin{array}{l}\underset{\tilde{Z}}{\tilde{Z}} \\
\stackrel{\tilde{\Xi}}{\oplus}\end{array}$ & 09 & 03 & 01 & 01 & 04 & 03 & 00 & 01 & 22 & $17.32 \%$ \\
\hline 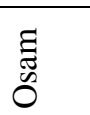 & 14 & 03 & 00 & 00 & 03 & 03 & 00 & 00 & 23 & $18.11 \%$ \\
\hline 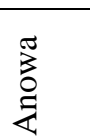 & 18 & 03 & 03 & 00 & 04 & 00 & 00 & 01 & 28 & $22.04 \%$ \\
\hline $\begin{array}{l}i=1 \\
01\end{array}$ & 29 & 09 & 01 & 00 & 09 & 02 & 00 & 03 & 53 & $40.94 \%$ \\
\hline 宫 & 00 & 00 & 01 & 00 & 00 & 00 & 00 & 00 & 01 & $0.78 \%$ \\
\hline Total & 70 & 17 & 06 & 01 & 20 & 08 & 00 & 05 & 127 & $100 \%$ \\
\hline
\end{tabular}

There are four main participants in the interaction, which can be divided into two (02) sections. Section one is an exchange between Osam and his wife, who discuss about the future of their daughter. On the whole, there seems to be an equal turn-taking in terms of the use of modal elements in this section of the conversation, for Badua is involved in 22 of the modal items used in the extract (17.32\%) whereas Osam authors 23 modal items (18.11\%). By contrast, in the section of the dialogue between Anowa and her husband, the majority of modal elements are actualized by Kofi. He utters 53 modalized and modulated clauses, representing $41.73 \%$ whereas Anowa uses 29 modal clauses, corresponding to $22.04 \%$. Thus, it is through modal elements that Kofi tries to deter his wife from pursuing her dreams of liberty and emancipation, which are expressed through her attitude toward cultural norms regarding marriage, the role of a woman in society, etc.

\subsection{Analysis of Adjunct Types in Extract 2}

Table 10 recapitulates the distribution of adjuncts among the participants: 
Table10: distributions of adjuncts types among the participants in Extract 2

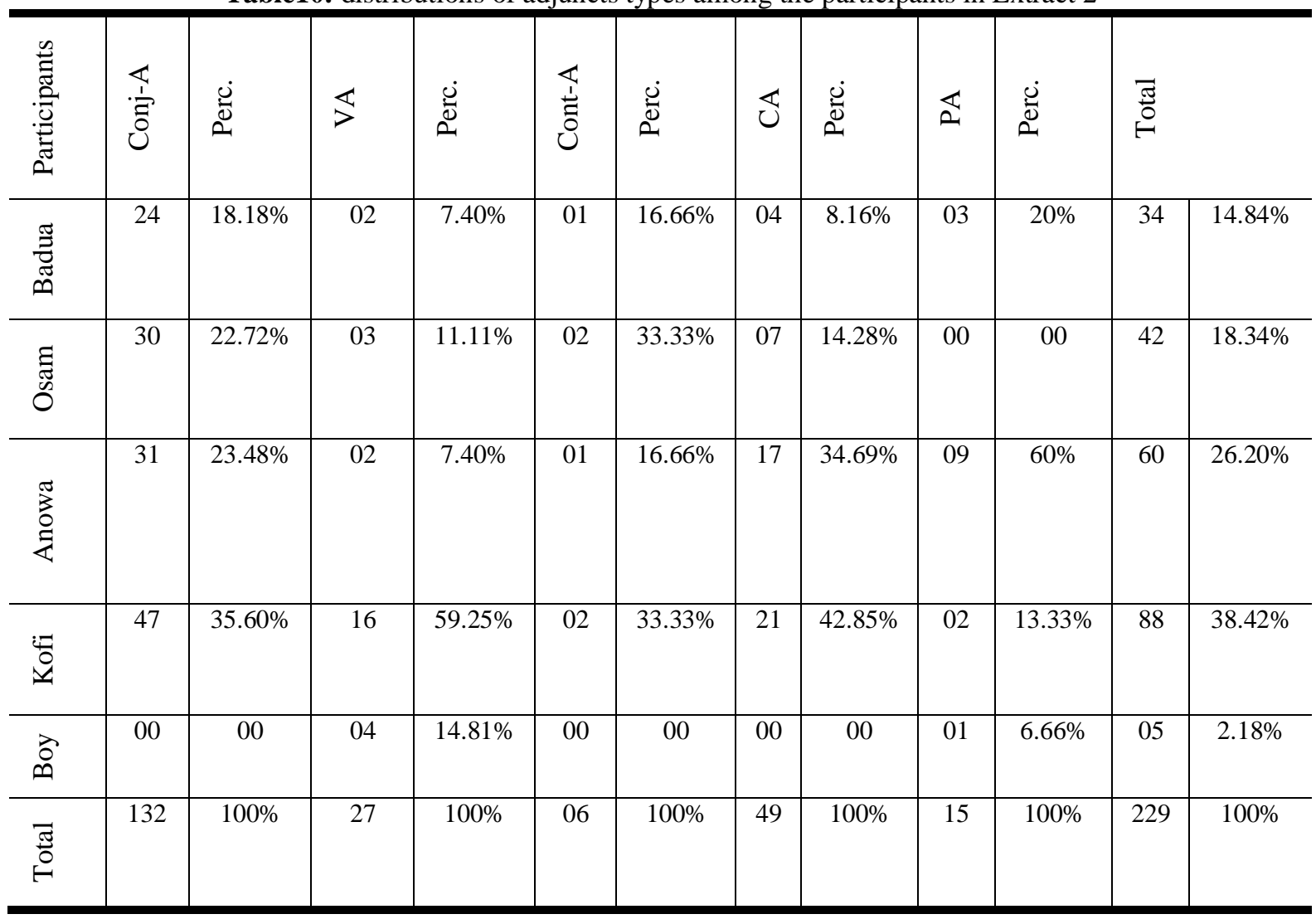

It comes out from the table that conjunctive adjuncts predominate in the extract and are mostly used by male characters to build up their arguments in a logic manner. Indeed, Osam utters 30 of them (22.72\%) and Kofi verbalizes $47(35.60 \%)$. While textual adjuncts contribute in creating coherence in the reasoning of the characters, vocative and polarity adjuncts connote meanings related to power, familiary, and intimacy among the participants. Kofi utters 16 of the 27 vocative adjuncts, corresponding to $59.25 \%$. He addresses his wife as "woman, Anowa" in clauses $(192,198,207$, $229,324)$ whereas she calls him "my master". He seems to affirm his power and authority as he realizes that these are trampled on by Anowa. Likewise, Osam addresses his wife as "woman, Badua, Nana" in vraious contexts clauses 105, 409, 16- to voice his exasperation as Badua contradicts him about the decision they have to make regarding Anowa's barrenness or her refusal to comply with social norms. Most of the PAs are used by Anowa to show her disagreement with her husband concerning the issue of slaves as said earlier. She utters 09 out of 15 PAs $(60 \%)$, which shows her rebellious spirit or character. Actually, she answers by saying "no" in $(275,304,308)$ without 
any form of modalisation or modulation to express her opinion in clauses (275, 304, 308). Even the "yes" in clause (244) may mean "no" in the context of the exchange. Circumstantial adjuncts have shown the context in which the exchange is carried out.

\section{Discussion and Interpretation of the Findings}

The texts have been split into numbered clauses and labelled interpersonally; here the task consists in giving them a meaning, for people do not simply interact but they exchange meanings. These meanings or narrations are raw materials on the basis of which new identities can be built, to use Obama's (2011) terms. The two extracts are basically concerned with exchanging information. Indeed, declaractive moods are predominant in the two extracts: they occur 199 times in extract 1, representing 68.15\%; and 250 times in extract 2 , representing $63.61 \%$. The analysis also reveals a significant number of minor clauses which are used 24 times [8.21\%] in extract 1 and quite in the same proportion in extract $2(24[6.10 \%])$. This shows that the exchange is realised in an informal context and that there is a familarity among the interactants.

The subject of the exchange is Anowa the main character's subversive attitude, her refusing to be a submissive woman whose main duty is to obey her husband and by extension society. She refuses to comply with traditional norms concerning marriage and married life. This is expressed -in extract 1 in such clauses as I have found the man I would like to marry (128-129); and it is none of your business, this is to be my marriage $(270,275)$. Anowa's attitude is abnormal according to society because marriage is a familial or tribal issue; thus, a girl cannot decide to choose her own husband and marry without due rituals. Anowa's husband's reaction is representative of what the society thinks of such behavior: you are a strange woman, Anowa. Too strange. You never even show much interest in what the oracles say (280-283). The oracles symbolize traditional values against which Anowa revolts and decides to live by her own principles.

Similarly, in extract two Anowa demonstrates her assertiveness by contradicting her husband about important issues regarding their family, notably the question of slavery in clauses such as no, no, no I don't want them. I don't need them (304-306); No! I just do not need them (308-309).

The statistics of the distribution of mood types among the participants show an active participation of female characters in the conversation in extract 1. Indeed, the turn-taking is dominated by Badua who actualizes $38.50 \%$ of the utterance. In fact, she uses more exclamatives (60\%), imperatives (58.82\%), and interogatives (44.44\%). While exclamative moods denote some anger or emotion, the imperative and interogative moods uttered by Badua reflect a kind of authority and boldness. Female charcters' attitude highlights 
a determination to change some traditional beliefs concerning women. Here a woman is not defined as an object that keeps silent and leaves the responsiblity to men alone; but she is verbally equiped to voice her concerns and ambitions.

This attitude arouses virulent reaction on the part of men-Kofi and Osam-in extract 2. They dominate the talk in this extract and manifestly show their disagreement as regards their wives assertiveness. Osam verbalizes 65 $(24.43 \%)$ clauses whereas his wife Badua is the participant for 45 (16.91\%). Likewise, Anowa's husband Kofi is involved in 81 clauses (30.82) in comparison to $71(26.69 \%)$ used by Anowa, his wife. The majority of imperatives and interrogatives are verbalized by men -Osam and Kofi. Osam is involved in $05(31.25 \%)$ imperatives compared to $02(12.5 \%)$ used by his wife; in 21 questions $(26.92 \%)$ compared to 14 (17.94\%) uttered by his wife. As far as Kofi is concerned, he is the participant for 26 question whereas his wife Anowa is the participant for 16 questions; he uses 09 imperatives whereas his wife uses only 02 imperatives. Thus, there is an explicit desire on the part of men to claim their authority and power as they realise that these are challenged by women.

The analysis of modality in the two extracts confirms what has been said eralier, that is, women play preeminent roles through the exchange. The majority of modulators is used by Badua, Osam's wife in extract 1; she uses 18 modulators out of $35(51.42 \%)$ and these connote meanings related to inclination, necessity, and obligation expressed though items such as will, shall, should, it is time, want in clauses (39, 51, 68, 117, 154,215). Osam expresses meanings in terms of possibilities or probailites, which denotes some passiveness by means of items like will, indeed, perhaps, would, could, I am sure in clauses $(172,180,185,186,232)$. Actuall, he is more concerned with abstractions as regards what would have been appropriate or traditionally normal whereas he is wife gives concrete orientations or recommandations.

However, the analysis of modality in extract 2 exudes that modal items or clauses are eseentially uttered by men. Osam is the participant for the majority of modalizers and modulators. He uses 19 (18.26\%) modalizers whereas Badua uses 16 of them (15.38\%); but Badua actualizes more modulators than her husband does, meaning that she is the one giving orientation or recommandation as regards her daughtor's marriage, as mentioned eralier. In the section of the exchange between Kofi and Anowa, the analysis reveals that modal items are mostly used by Kofi: he uses 44 modalizers (42.30) in comparison with $24(23.07 \%)$ used by his wife; he uses $15(51.72 \%)$ modulators in comparison with $04(13.79 \%)$ used by his wife. Thus, Kofi seems to reaffirm his authority over his wife. On the whole, it comes out from the analysis of modality that the relationship between female and male characeters is flexible in terms of power, familiarity, and solidarity, that is, there are no fixed borders. 
The last linguistics tools that need to be taken into account within the ramework of this reflexion are adjuncts. 73 out $164(44.51 \%)$ are used by Badua in extract 1, which means, as said eralier, that she monopolises the turntaking; whereas in extract 2 the majority of adjuncts are used by men who dominate the talk. Kofi is the participant for 88 adjuncts, representing $38.42 \%$, and Osam verbalizes 42 adjuncts, corresponding to $18.34 \%$. Osam uses the adjunct my wife in clauses $(15,35,78,174,216)$, but in clause $(8,169)$ he adresses her as woman, Abena badua. This denotes affection or intimacy and solidarity on the one hand, and on the other hand his attitude connotes authority. Actually, he expresses a certain respect and a tendancy to listen and understand, but he does not accept any idea advanced by his wife. Badua calls her husband Kofi sam, Osam, Kobina sam in clauses (10, 14, 168), and my hysband in clauses $(50,77)$. Culturally, her attitude can be interpreted as stuborness and willpower. In extract 2, the same remark can be made as regards Anowa's behavior in clauses such as what I don't understand, Kofi, is why you want to have so many things your own way; Kofi, what are you saying?; Kofi, I am hearing right; Kofi I shall get you a wife, etc. (17, 76, 109, 304). On the whole, the analysis of adjuncts reveals a tenor of equal respect and power between men and women.

\section{Conclusion}

The analysis of two extracts from Anowa, a play written by Aidoo, has been carried out interpersonally on the basis of both the qualitative and quantitative methods so as to understand what characterizes the relationship between men and women and to which extend this relationship is redefined. The thorough analysis of the two extracts exudes that the exchange between female characters and male characters is realized in a context of familiarity, equal power, and mutual respect; though men tend to be reluctant concerning their wives' assertiveness. This tenor does not correspond to the traditional roles of women as defined by the patriarchal system, for the female characters are equipped verbally and intellectually to voice their feelings and beliefs. Thus, in Anowa a woman does not simply undergo things, but she creates her own narrations; she builds her own realities and lives by them at the risk of being rejected. However, it is not a total rejection of the patriarchal system but an adaption or an improvement of this system. This seems to be the message of the author -Ama Ata Aidoo- through Anowa.

\section{References:}

1. Obama, B. (2011). Les Rèves de mon Père. Traduit de l'Anglais (Etats Unis) par Danièle Darneau. Saint-Amand-Montrond (Cher) : Press de la Cité. Burck, C. (2005). "Comparing qualitative research methodologies for systemic research: the use of grounded theory, 
discourse analysis and narrative analysis". Journal of Family Therapy, (27), 237-262. .

2. Creswell, W. J. (Eds) (2014). Research design: qualitative, quantitative, and mixed methods approaches. London: SAGE Publication, Inc.

3. Eggins, S (1994). An introduction to Systemic functional Linguistics. London: Printer publisher.

4. Halliday, M.A.K \& Matthiessen, C.I.M (2004) . An Introduction to Functional Grammar. London: Hodder Headline Group.

5. Ibeku, I. A. (2015). "Adichie's Purple Hibiscus and the Issue of Feminism in African Novel". Journal of Literature and Art Studies, 6 (5), 426-437.

6. Koussouhon, L. \& Dossoumou, M. A. (2014). "Lexico-Grammatical Analysis of Yellow-Yellow by Kaine Agary with a Focus on Experiential and Textual Meanings". Mediterranean Journal of Social Sciences, 23 (5), 2430-2438.

7. Okafor, G. C (2002). "African Literature and Beauvoirism: The Example of Selected Women's Action and Women Writers". Paris: Syllepse, 259-268.

8. Sheikh, B. K. \& Ahmad, S. (2015). "The Role of English in ReConstruction Society". Journal of Culture, Society and Development. 2224-8400.

9. Sylvester, M. (2009). "Through a Female Lens: Aspects of Masculinity in Francophone African Women's Writing". Unpublished Thesis. University of Arizona.

10. Song, Z. (2013). "Transitivity Analysis of A Rose for Emily". Theory and Practice in Language Studies, 12 (3), 2291-2295.

11. Strong-Leek, L. (2011). "Reading as a Woman: Chinua Achebe's Things Fall Apart and Feminist Criticism". African Studies Quarterly, 2 (5), 29-35. 


\section{Appendices}

The following keys have been used:

$\begin{array}{ll}\text { DM } & \text { Declarative Mood } \\ \text { ImpM } & \text { Imperative Mood } \\ \text { IntM } & \text { Interrogative Mood } \\ \text { EX } & \text { Exclamative Mood } \\ \text { MC } & \text { Minor Clause } \\ \mathrm{M}^{+} \text {DM } & \text { Modulated declarative Mood } \\ \mathrm{M}^{+} \text {ImpM } & \text { Modulated Imperative Mood } \\ \mathrm{M}^{-} \mathrm{DM} & \text { Modalized Declarative Mood } \\ \mathrm{M}^{-} \text {ImpM } & \text { Modlaized Imperative Mood } \\ \mathrm{M}^{+} \text {IntM } & \text { Modulated Interrogative Mood } \\ \mathrm{M}^{-} \text {IntM } & \text { Modlaized Interrogative Mood } \\ \mathrm{M}^{+} & \text {Modulator } \\ \mathrm{M}^{-} & \text {Modalizer } \\ \mathrm{MA}^{-} & \text {Mood Adjunct } \\ \text { PA } & \text { Polarity Adjunct } \\ \text { CA } & \text { Cicumstantial Adjunct } \\ \text { Co-A } & \text { Comment Adjunct } \\ \text { VA } & \text { Vocative Adjunct } \\ \text { Cont-A } & \text { Continuity Adjunct } \\ \text { Conj-A } & \text { Conjunctive Adjunct }\end{array}$

Extract 1 (Anowa, 1970: 103-107)

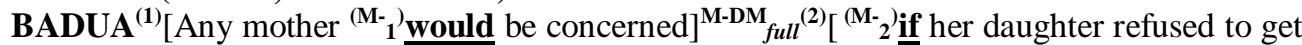
married six years after her puberty. ${ }^{\mathbf{M}^{-D M}}{ }_{\text {full }}{ }^{(\mathbf{3})}\left[{ }^{\left(\mathbf{M}-\mathbf{3}_{3}\right)} \text { If I do not worry about this, }\right]^{\mathbf{M}^{\mathbf{M}-\mathbf{D M}_{\text {full }}}{ }^{(\mathbf{4})}[\text { what }}$ ${ }^{\left(\mathbf{M}_{1}\right)}$ shall I worry about?] ${ }^{\mathbf{M}+\mathbf{D M}}{ }_{\text {full }}$ (OSAM enters from upper left smoking his pipe.)

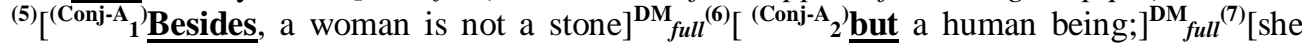
grows. $]^{\text {DM }}{ }_{\text {full }}$

OSAM $^{(8)}\left[{ }^{\left(\mathbf{V A}_{1}\right)} \text { Woman, (BADUA tums to look at him) that does not mean }\right]^{\mathbf{D M}_{\text {full }}{ }^{(\mathbf{9})}[\mathrm{you}}$ $\left(\mathbf{M}_{2}{ }_{2}\right.$ should break my ears with your complaints. ${ }^{\mathbf{M}+\mathbf{D M}_{\text {full }} \text { (He looks verycomposed.) }}$

BADUA ${ }^{(10)}$ [What did you say, $\left.{ }^{\left({ }^{\left({ }_{2}\right.}\right)}{ }_{2}{ }_{\text {Osam? }}\right]^{\text {IntM }_{\text {full }}}$

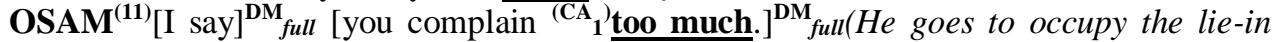
chair, and exclaims, 'Ah!' with satisfaction,)

BADUA(seriously) ${ }^{(\mathbf{1 2})}$ [Are you trying to send me insane? ${ }^{\text {IntM }_{\text {full }}}$

OSAM $^{(13)}\left[{ }^{\left(\mathbf{M}-{ }_{4}\right)} \text { will that shut you up? }\right]^{\text {M-IntM }}{ }_{\text {full }}$

BADUA ${ }^{(14)}\left[{ }^{\left({ }^{(}{ }_{3}\right)} \text { Kofi Sam! }\right]^{\mathrm{MC}}{ }_{\text {ex }}$ (Now she really is angry.)

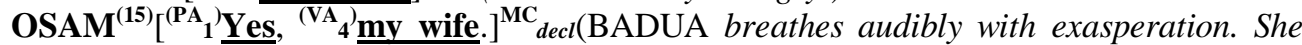
begins pacing up and down the courtyard, with the ladle in her hand.)

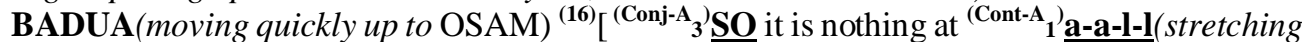
the utterance of the last word) to you that $]^{\mathbf{I n t M}}{ }_{\text {full }}{ }^{(17)}$ [your child is not married] ${ }^{\mathbf{D M}}{ }_{\text {full }}{ }^{(\mathbf{1 8})}\left[{ }^{(\mathbf{C o n j}-}\right.$ ${ }_{4}{ }_{4}$ and goes round wild, making everyone talk about her?] ${ }^{\mathbf{D M}_{\text {full }}}$

OSAM ${ }^{(\mathbf{1 9})}$ [Which is your headache, that $]^{\mathbf{I n t M}}{ }_{\text {full }}{ }^{(\mathbf{2 0})}[\text { she is not yet married, }]^{\mathbf{D M}}{ }_{\text {full }}{ }^{(\mathbf{2 1})}\left[{ }^{(\mathbf{C o n j}-}\right.$

$\mathbf{A}_{5}$ ) or that she is wild? $]_{\text {full }}^{\mathbf{D M}_{\text {ful }}}$

BADUA ${ }^{(22)}\left[{ }^{\left({ }^{(n t e r j}{ }_{1}\right)} \mathbf{H m m} !^{\mathrm{MC}}{ }_{e x}\right.$

OSAM $^{(23)}\left[{ }^{\left({ }^{(M-}-{ }_{5}\right)} \text { You know that }\right]^{\text {DM }}{ }_{\text {full }}{ }^{(24)}[\mathrm{I} \text { am a man }]^{\text {M-DM }}{ }_{\text {full }}{ }^{(25)}{ }^{\left({ }^{(C o n j-A}\right)}$ and getting daughters

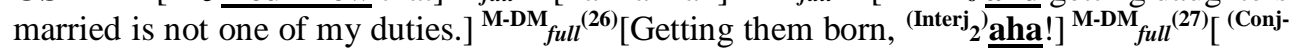
${ }_{7}{ }_{7}$ But not finding them husbands. ${ }^{\text {M-DMM }}{ }_{\text {full }}$

BADUA $^{(28)}\left[{ }^{\left({ }^{(n t e r j}{ }_{3}\right)} \mathbf{H m m} !\right]^{\mathbf{M C}_{\text {ex }}}$ (Paces up and down.)

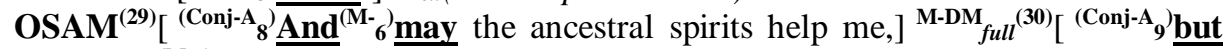
what man ${ }^{\left(\mathbf{M}_{7}\right)}$ would I order from the heavens to please the difficult eye of my daughter Anowa?] ${ }^{\text {M-Int }}$ full 


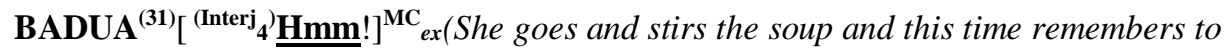
put the ladle down. She stands musing by the hearth.)...

Extract 2 (Anowa, 1970: p.112-114)

BADUA ${ }^{(1)}[\mathrm{I} \text { haven't heard the like of this before. }]^{\mathbf{D M}_{\text {full }}}{ }^{(2)}\left[\mathrm{A}\right.$ human being, and ${ }^{\left(\mathrm{Conj}^{-A} \mathbf{1}^{2}\right.}$ a woman $\underline{\text { too }}^{(\mathrm{Conj-A}}{ }^{2}$, preferring to ${ }^{\left(\mathrm{M}+{ }_{1}\right)}$ remain a stranger in other people's lands? ${ }^{\mathrm{M}+\mathrm{DM}}{ }_{\text {full }}$

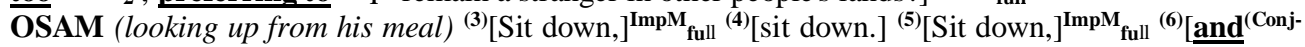

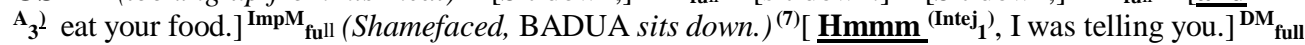

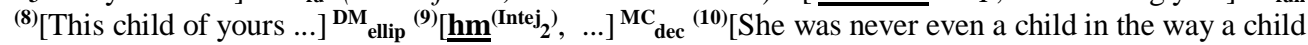
must $^{\left(\mathrm{M}+2_{2}\right.}$ be a child.] ${ }^{\mathrm{M}+\mathrm{DM}_{\text {ful }}}$

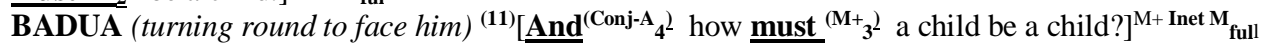

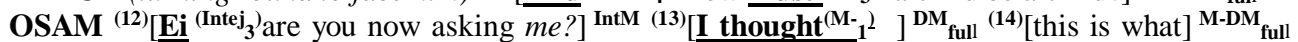

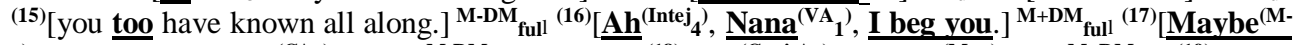

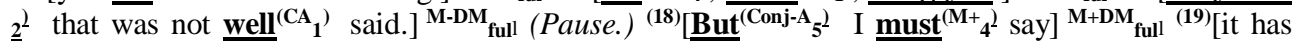
happened before us all. $]^{\mathbf{D M}}$ full ${ }^{(20)}\left[\text { Has it not? ] }{ }^{\text {InM }}{ }_{\text {ellip }}{ }^{(21)} \text { [Walked out of that door, }\right]^{\mathbf{D M}_{\text {full }}}{ }^{(22)}$ [she

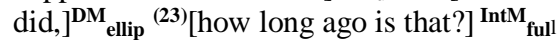

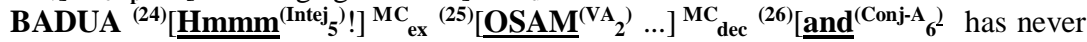
been back since. $]^{\mathbf{D M}_{\text {full }}}{ }^{(27)}$ [I have always ${ }^{\left(\mathbf{M}-{ }_{3}\right.}$ feared her. ${ }^{\mathbf{M}-\mathbf{D M}_{\text {full }}}$ BADUA (shocked) ${ }^{(28)}$ [You have always ${ }^{\left({ }^{(\mathbf{M}}\right.}{ }^{2}$ feared her?] ${ }^{\text {M-IntM }}{ }_{\text {full }}{ }^{(29)}\left[\right.$ And $^{\left(C^{(C o n j-A}\right.}{ }_{7}$ is that a good thing

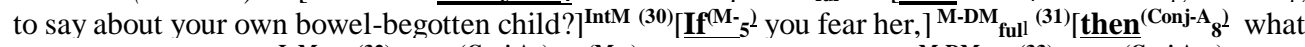

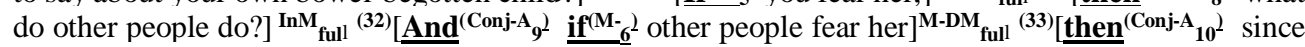
a crab never fathers a bird, in their eyes, ${ }^{\mathbf{D M}}{ }_{\text {full }}{ }^{(34)}$ [who are you yourself? $]^{\text {IntM }_{\text {full }}}{ }^{\left({ }^{35}\right)}$ [After all, what has

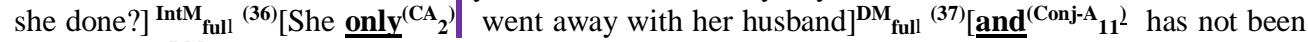
back since.] ${ }^{\text {DM }_{\text {full }}}$

$\operatorname{OSAM}^{\left({ }^{(3)}\right)}$ And $^{\left(\mathrm{Conj-A}_{12}^{2}\right.}$ that, you will ${ }^{\left(\mathrm{M}_{7}\right)}$ agree with me, ${ }^{\mathrm{M}-\mathrm{DM}}{ }_{\text {full }}{ }^{\left({ }^{39}\right)}\left[{ }_{\text {is }} \underline{\text { very }}^{\left(\mathrm{CA}_{3}\right)}\right.$ strange. $^{\mathrm{DM}_{\text {full }}}$

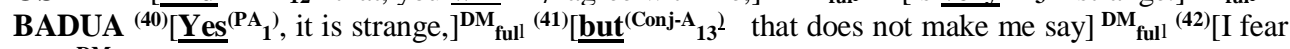

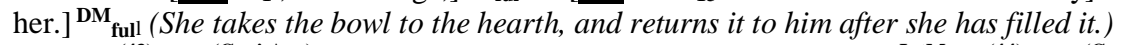

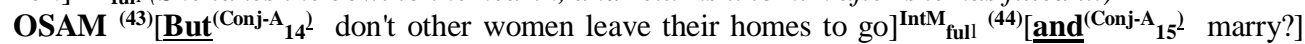
IntM $_{\text {full }}{ }^{\left({ }^{(5)}\right)}\left[\right.$ And $^{\left({ }^{(C o n j-A}\right.}{ }_{16}{ }^{2}$ do they stay away forever?] ${ }^{\text {IntM }_{\text {full }}}{ }^{(46)}$ [Do they not return with their children to

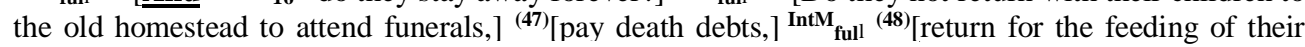

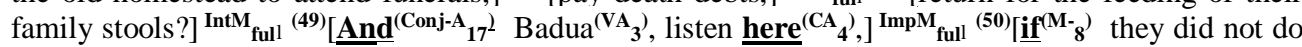

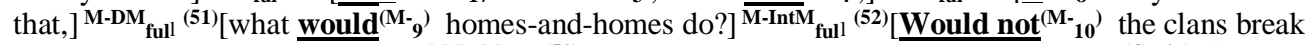
up for lack of people at home] ${ }^{\text {M-IntM }}{ }_{\text {full }}{ }^{(53)}\left[\right.$ The children of women like Anowa and $^{\left(\text {Conj-A }_{18}{ }^{2}\right.}$ their

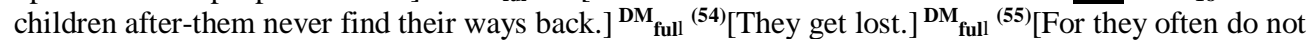
know the names of the founders of their houses ... ${ }^{\mathbf{D M}}{ }_{\text {full }}{ }^{(56)}{ }^{\left(\mathbf{N o}^{\left(\mathbf{C o n t}_{-}\right.} \mathbf{1}_{1}\right)}$, they do not know what to tell

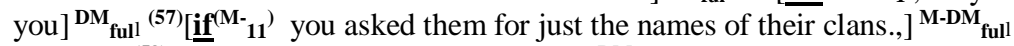

BADUA ${ }^{(58)}$ [Anowa has not yet had children.] ${ }^{\text {DM }_{\text {full }}}$

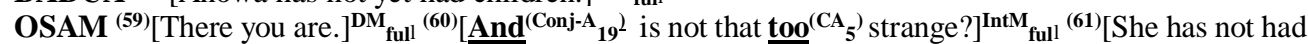

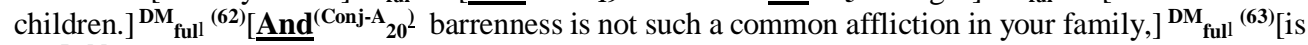
it?] ${ }_{\text {IntM }}^{\text {full }}$

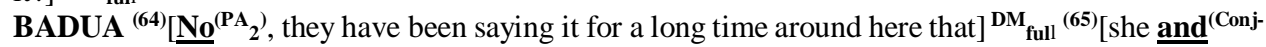
$\mathbf{A}_{\mathbf{2 1}}$ ' her husband sold her birth-seeds to acquire their wealth.] ${ }^{\mathbf{D M}_{\text {full }}}$

OSAM ${ }^{\left({ }^{6} 6\right)}\left[\text { Of course }^{\left(\mathrm{M}_{12}\right)} \text {, women have mouths to talk with. }\right]^{\mathrm{M}-\mathrm{DM}}{ }_{\text {full }}{ }^{\left({ }^{67}\right)}\left[\right.$ And $^{\left(\mathrm{Conj}_{-\mathrm{A}} \mathbf{2 2}^{2}\right.}$ indeed $^{\left(\mathrm{M}-{ }_{13}\right)}$

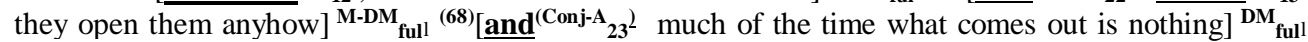

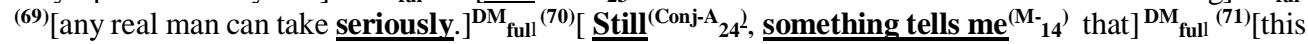
time she has given them cause. $]^{\text {M-D. }}$ full $_{\text {ful }}$

BADUA ${ }^{(72)}\left[\underline{\mathbf{O}}^{\left(\text {Intej }{ }_{6}\right)} \underline{\text { Kofi Sam }}^{(\mathrm{VA})}{ }_{4}^{!}\right]^{\mathrm{MC}}{ }_{\text {ex..... }}$ 